\title{
Xenomas in Crassostrea rhizophorae (Ostreidae) from Camamu Bay, Bahia, Brazil
}

\author{
Boehs, G. ${ }^{\text {a* }}$ Lenz, TM. ${ }^{\text {a* }}$ and Villalba, A. ${ }^{\text {b* }}$

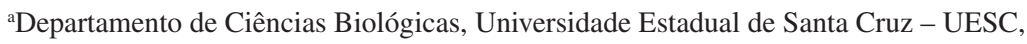 \\ Rod. Ilhéus-Itabuna, Km 16, CEP 45650-000, Ilhéus, BA, Brazil \\ ${ }^{\text {b} C o n s e l l e r i ́ a ~ d e ~ P e s c a ~ e ~ A s u n t o s ~ M a r i ́ t i m o s, ~ C e n t r o ~ d e ~ I n v e s t i g a c i o ́ n s ~ M a r i n ̃ a s ~-~ C I M A, ~}$ \\ Xunta de Galicia, Apdo. 13, Vilanova de Arousa 36620, Spain \\ *e-mail: gboehs@uesc.br, tiagopesca@hotmail.com, villalba@cimacoron.org \\ Received October 16, 2008 - Accepted October 29, 2008 - Distributed May 31, 2009
}

(With 1 figure)

This paper reports the occurrence of xenomas in the mangrove oyster Crassostrea rhizophorae (Guilding, 1828) gills. Xenomas are formed when intracellular parasites accumulate within host cells, causing hypertrophy of the cell and its nucleus. In fish, the xenomas are commonly caused by microsporidians (Matos et al., 2003), but in the oyster Crassostrea virginica (Gmelin) they are caused by ciliates, genus Sphenophrya (Bower et al., 1994; Winstead et al., 2004; Scarpa et al., 2006). In Brazil, Nascimento et al. (1986) observed such organisms in C. rhizophorae from Todos os Santos Bay (Bahia), but these authors didn't make reference to xenoma formation. Thus, the present study is the first report of xenomas in C. rhizophorae. A total of 394 oysters were monthly collected between August 2006 and August 2007 in the Maraú

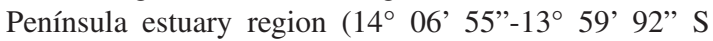
and 39 02 ' 83" $-38^{\circ}$ 59' 92" W), Camamu Bay (Bahia, Brazil), on roots of the red mangrove Rhizophora mangle L.. The oysters were measured (dorso-ventral axis) and shucked. Meat fragments were kept in Davidson's fixative solution (Shaw and Battle, 1957) for 24-30 hours, and then transferred to $70 \%$ ethanol. The material was processed for histology, with paraffin embedding, production of $7 \mu \mathrm{m}$ thick sections and staining with Harris hematoxilin and Eosin (HE). The sections were examined with light microscopy. The water temperature ranged from 23.5 to $30{ }^{\circ} \mathrm{C}$ and the salinity from 15 to 35 . The height of the oysters ranged from 2.7 to $10.2 \mathrm{~cm}$ and the xenomas occurred in animals measuring between 4.3 to $5.5 \mathrm{~cm}$. The prevalence of xenomas was $2.53 \%$ (10/394). As reported in C. virginica (Bower et al., 1994; Winstead et al., 2004; Scarpa et al., 2006), the xenomas of $C$. rhizophorae were, very probably, caused by ciliates, genus Sphenophrya. The xenomas were formed in the gills epithelium (Figure 1). According to Bower et al. (1994), single Sphenophrya-like ciliates can also be observed attached on palps and possibly on the mantle of oysters. Unlike what has been reported in C. virginica (Scarpa et al., 2006), no macroscopic evi-
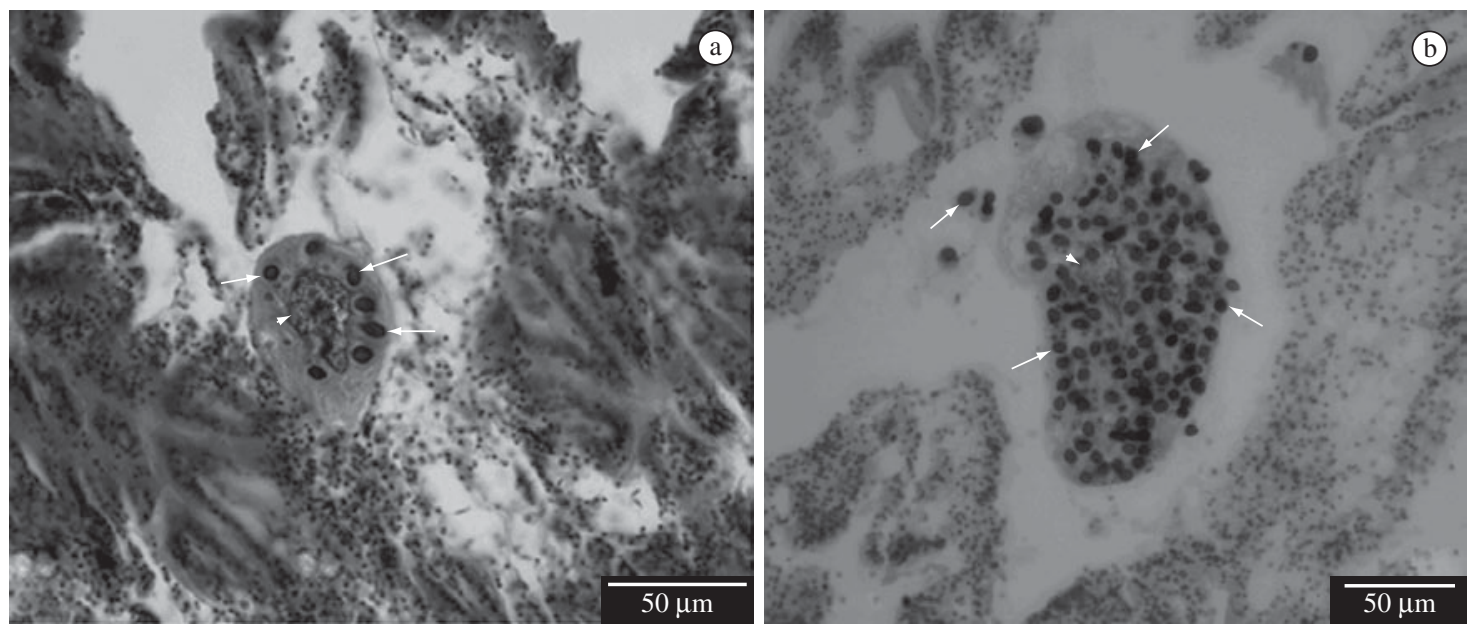

Figure 1. Xenomas in the gills of the mangrove oyster Crassostrea rhizophorae, a) in earlier and b) more advanced stage. Arrows $=$ ciliates ; arrowheads $=$ nucleus of the host cell . 
dence of xenomas was observed, and only 1-2 xenomas were observed per histological section. In $C$. virginica, Scarpa et al. (2006) observed densities mostly below 20 xenomas per histological section, but they reached as high as 173 . With regard to prevalence, Nascimento et al. (1986) reported Sphenophrya-like in 2\% of the oysters C. rhizophorae from Todos os Santos Bay (Bahia, Brazil), which is similar to the results found in this study (2.53\%). In C. virginica, Winstead et al. (2004) estimated prevalence lower than $1 \%$ and Scarpa et al. (2006) observed values between 1 and $82 \%$. According to Scarpa et al. (2006), the xenomas cause localized epithelial erosion and most likely impede water flow. Due to the low prevalence and intensity, we conclude that the xenomas are no threat to the oyster population in Camamu Bay so far.

Acknowledgements - This study was supported by the Financiadora de Estudos e Projetos - FINEP (MCT, Brazil), Fundação de Amparo à Pesquisa do Estado da Bahia - FAPESB, and Fundación Carolina (Spain).

\section{References}

BOWER, SM., McGLADDERY, SE. and PRICE, IM., 1994. Synopsis of Infectious Diseases and Parasites of Commercially Exploited Shellfish. Annu. Rev. Fish Dis., vol. 4, p. 1-199.

MATOS, E., CORRAL, L. and AZEVEDO, C., 2003. Ultrastructural details of the xenoma of Loma myrophis (phylum Microsporidia) and extrusion of the polar tube during autoinfection. Dis. Aquat. Org., vol. 54, p. 203-207.

NASCIMENTO, IA., SMITH, DH., KERN II, F. and PEREIRA, SA., 1986. Pathological findings in Crassostrea rhizophorae from Todos os Santos Bay, Bahia, Brazil. J. Invertebr. Pathol., vol. 47, p. 340-349.

SCARPA, E., FORD, S., SMITH, B., BUSHEK, D., 2006. An investigation of ciliate xenomas in Crassostrea virginica. J. Shellfish Res., vol. 25, p. 772-773.

SHAW, BL. and BATTLE, HI., 1957. The gross and microscopic anatomy of the digestive tract of the oyster Crassostrea virginica (Gmelin). Can. J. Zool., vol. 35, p. 325-347.

WINSTEAD, JT., VOLETY, AK. and TOLLEY, SG., 2004. Parasitic and symbiotic fauna in oysters (Crassostrea virginica) collected from the Caloosahatchee River and estuary in Florida. J. Shellfish Res., vol. 23, p. 831-840. 